\title{
QUALITY OF LIFE CHANGES IN POST-MENOPAUSAL WOMEN WITH OSTEOPOROSIS AFTER SHORT TERM TAI CHI EXERCISE PROGRAM
}

\author{
Ema Lašinytė, Kristina Berškienė, Vilma Mauricienė \\ Lithuanian University of Health Sciences, Institute of Sports
}

Key words: osteoporosis, SF-36 questionnaire, Tai Chi.

\begin{abstract}
Summary
Objectives. To evaluate quality of life changes in post-menopausal women with osteoporosis after application of Tai Chi exercise program.

Material and methods. 13 post-menopausal women with osteoporosis participated in the study which included application of Tai Chi exercise program for eight weeks. Two, one-hour group training sessions were taught per week. Quality of life was assessed two times: before and after eight weeks of Tai Chi program. Quality of life measurements were conducted using SF-36 questionnaire.

Results. Research data showed statistically significant changes $(p<.05)$ in three of eight SF-36 fields after application of Tai Chi exercise program: bodily pain, general health perception and emotional role functioning while no significant changes were observed in other five fields ( $\mathrm{p} \geq .05)$.

Conclusions. Obtained results showed positive changes in Physical and Mental component areas. However, further future research is still needed to find out how Tai Chi program would affect other fields of the life.
\end{abstract}

\section{Introduction}

Osteoporosis is the result of metabolic disease of the osseous system characterized by reduced bone mineral density (1). The appearance of osteoporosis in elders and the growth of the frequency of this disease makes this health problem so relevant in the societies in which a high number of persons reach old age (2).

The evaluation of the quality of life has become a very important part of scientific researches, involving various components of life aspects (2). As osteoporosis progresses slowly and imperceptibly, it is often not diagnosed in time and can occur unexpectedly. Slowly progressing factors as osteoporosis-induced skeletal deformities, joint imbalance and tension in muscular structures have a negative impact on normal physical functioning (3). Often, these factors lead to severe or intolerable back pain (3), which not only limits physical activity but also affects mental state (1) which is associated with reduction in health-related quality of life (4).

Although the quality of life is certainly an important aspect of scientific research, effects of Tai Chi on quality of life changes are often analyzed in context of other research objects (balance, muscle strength etc.) (2). However, analysis of the existing scientific publications shows that Tai Chi could have a positive impact on quality of life. Therefore, among the studies which investigate impact of Tai Chi on post-menopausal women with osteoporosis, exploration of quality of life changes is still not common and the results are not entirely clear.

The aim of this study was to evaluate quality of life changes in post-menopausal women with osteoporosis after application of Tai Chi exercise program.

\section{Material and methods}

Subjects. Study included 13 post-menopausal women with osteoporosis. The average age was 74.2 years (the range of the age was $67-81$ years), the average height was 158.6 $\mathrm{cm}$, the average weight was $67.1 \mathrm{~kg}$. All women belonged to Kaunas district osteoporosis club "Uola" and participation in the study was voluntary. The study received the approval of the Bioethics Center of Lithuanian University of Health Sciences (No. BEC - SR(M) - 134). All participants signed a statement of informed consent after receiving information about the course of investigation and its methods.

Research protocol. The quality of life was evaluated using SF-36 questionnaire. The assessment was performed two times: before Tai Chi exercise program and after eight weeks of application of Tai Chi exercise program.

SF-36 questionnaire consists of 36 questions that reflects eight fields of the life: physical functioning, role limitations because of physical health problems (physical role functioning), bodily pain, general health perceptions, vitality (energy/fatigue), social functioning, role limitations because 
of emotional problems (emotional role functioning), general mental health (psychological distress and psychological wellbeing) (5). The SF-36 can also be divided into two parts: the Physical Component Area (PCA) which includes the abovementioned first four fields of life and the Mental Component Area (MCA) which includes the rest four fields (5).

Physical functioning, physical role functioning, bodily pain, social functioning and emotional role functioning define health status in terms of the absence of disability while general health perceptions, vitality and general mental health areas covers both positive and negative health states.

The scores are weighted sums of the questions in each section. Scores range from $0-100$. Lower scores mean more disability while higher - less disability in particular area of the life (5).

Tai Chi exercise program. The exercise program lasted for eight weeks. Sessions were held twice a week (16 Tai Chi sessions at total). The duration of each session was 60 min. Tai Chi sessions were initiated with 5 - 10 min duration of introductory warm-up exercises, $40-45 \mathrm{~min}$ of the main part of Tai Chi and 5-10 min of relaxation exercises. The main part of Tai Chi session consisted of eight basic Tai Chi movements as well as static stances for the body's center of mass training. Moreover, dynamic exercises, integrating coordinated feet - hand movements and breathing, were taught. Dynamic exercises were selected from Wudang Tai Chi Sanfeng $13^{\text {th }}$ form, according to functional capacity of participants. Exercises got progressively more difficult by the course.

\section{Statistical analysis}

The obtained data was analyzed using SPSS 22.0. The non-parametric Wilcoxon's test for 2-related samples was used. The level of statistical significance was set at $p<0.05$.

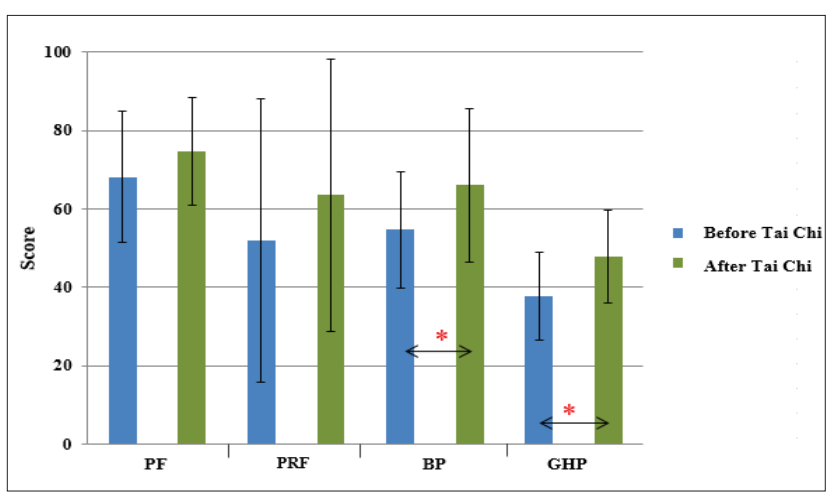

Figure 1. Physical Component Area results before and after Tai Chi exercise program

Note. PF - Physical Functioning, PRF - Physical Role Functioning, BP - Bodily Pain, GHP - General Health Perception. * $p<.05$

\section{Results}

Physical Component Area. After the assessment of quality of life, we found that before Tai Chi exercise program the average value at "Physical Functioning" field was 68.08 points while after eight weeks of program the average value was 74.62 points. This change was not statistically significant $(\mathrm{Z}=-1.340, \mathrm{p}=0.180)$.

Analyzing results from "Physical Role Functioning" field, we found that the average value before application of Tai Chi program was 51.92 points. After Tai Chi exercise program the value was 63.46 points and this change was not significant $(Z=-1.045, p=0.296)$ (Figure 1).

The findings of the SF-36 questionnaire section "Bodily Pain" revealed that before Tai Chi program the average value at this section was 54.62 points but after the program the average value increased to 66.00 points, which means that pain felt in the body decreased. Changes in "Bodily Pain" field were statistically significant $(Z=-2.150, p=0.032)$.

Significantly better results were also observed at "General Health Perception" field. Before Tai Chi exercise program the average value of this field was 37.69 points and after eight weeks of program it was 47.69 points. Obtained results statistically significantly improved after application of Tai Chi program compared to pre-exercise program results $(\mathrm{Z}=-2.060, \mathrm{p}=0.039)$.

Mental Component Area. The SF-36 questionnaire "Vitality" field average value before program was 51.92 points. After application of Tai Chi exercise program the average value at this field was 59.62 points but the change was not statistically significant $(\mathrm{Z}=-1.737, \mathrm{p}=0.082)$.

After eight weeks of the program, the average value at "Social Functioning" field was 71.46 points. Compared to pre-program measurements (66.85 points), the result did

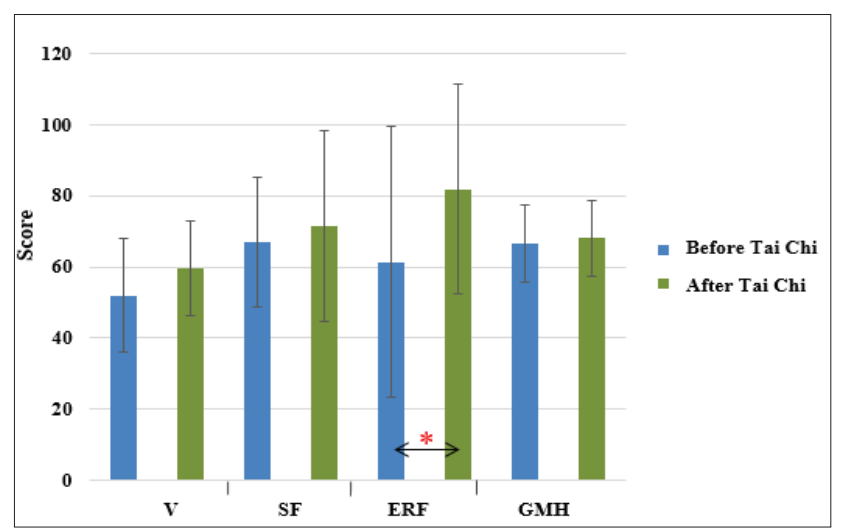

Figure 2. Mental Component Area results before and after Tai Chi exercise program

Note. $V$ - Vitality, $S F$ - Social Functioning, ERF - Emotional Role Functioning, $G M H$ - General Mental Health. ${ }^{*} p<.05$ 


\section{6}

not change significantly $(\mathrm{Z}=-1.368, \mathrm{p}=0,171)$ (Figure 2$)$.

Findings of "Emotional Role Functioning" field showed that before Tai Chi program the average value was 61.31 points while after eight weeks of program the average value at this field was 81.92 points. The measured change was statistically significant $(Z=-2.032, p=0.042)$ which means that role limitations because of emotional problems were lower after Tai Chi exercise program.

Comparing the results from "General Mental Health" section before and after application of Tai Chi exercise program, we found that before program the average value at this field was 66.46 points. After eight weeks of Tai Chi program the value has changed and was 68.00 points although the change was not significant $(\mathrm{Z}=-1.127, \mathrm{p}=0.260)$.

\section{Discussion}

With growing scientific evidence that osteoporosis-induced physical changes and limitations of daily activities are associated with poorer quality of life indicators (6), the most recent researches begins to look for various interfaces between different training programs and quality of life changes (4). For example, statistically significantly $(\mathrm{p}<0.001)$ lower results in all SF-36 questionnaire domains were measured in elderly patients with osteoporosis compared with control group (6).

Chyu and co-authors, analyzing Tai Chi effects of postmenopausal women with decreased bone mineral density (BMD), found statistically significant improvement in quality of life in terms of general health perception $(\mathrm{p}=0.008)$, vitality $(\mathrm{p}=0.02)$ and bodily pain $(\mathrm{p}=0,03)$ after 24 -weeks of Tai Chi exercise program (7).

Other researchers analyzed the effects of Tai Chi on $\mathrm{BMD}$, bone turnover markers and quality of life in postmenopausal women with osteopenia. After three month of Tai Chi exercise program, statistically significantly better results in Physical Component Summary ( $\mathrm{p}=0.02$ ) of SF-36 questionnaire were measured (8). Our study results revealed statistically significant improvement in bodily pain $(\mathrm{p}=0.032)$ and general health perception $(\mathrm{p}=0.039)$ areas after two months of application of Tai Chi exercise program. These results are consistent with Chyu and co-authors study's results (7).

In addition, Wayne with colleagues (8) did not detect any significant changes in Mental Component Summary after three months of Tai Chi exercise program, but our research showed statistically significantly better results in "Role limitations because of emotional problems" ( $\mathrm{p}=0.042)$ area.

\section{Conclusions}

The research results demonstrated quality of life improvement both in the Physical and Mental component areas after application of two months Tai Chi exercise program. There is still a need for further longer-term studies to find out whether Tai Chi program would affect other fields of the life.

\section{References}

1. Bączyk G, Samborski W, Jaracz K. Evaluation of the quality of life of postmenopausal osteoporotic and osteopenic women with or without fractures. Arch Med Sci 2016;12(4):819-27. https://doi.org/10.5114/aoms.2015.55012

2. Abobului M, Berghea F, Vlad V, Balanescu A, Opris D, Bojinca $\mathrm{V}$ et al. Socio-economical factors that influence the perception of quality of life in patients with osteoporosis. J Med Life 2015; 8(Spec Issue): 109-114.

3. Paolucci T, Saraceni VM, Piccinini G. Management of chronic pain in osteoporosis: challenges and solutions. J Pain Res 2016; 9: $177-186$.

https://doi.org/10.2147/JPR.S83574

4. Barcenilla-Wong AL, Chen JS, Cross MJ, March LM.. The impact of fracture incidence on health related quality of life among community-based postmenopausal women. J Osteoporos 2015; 2015: 717914 . https://doi.org/10.1155/2015/717914

5. Ware JA. SF-36® Health Survey (Version 1.0): Instrument review. Australian Health Outcomes Collaboration (AHOC). University of Wollongong. Centre for Health Service Development 2005.

6. Ma L, Li Y, Wang J, Zhu H, Yang W, Cao R. et al. Quality of life is related to social support in elderly osteoporosis patients in a Chinese Population. PLoS ONE. 2015;10(6): e0127849. https://doi.org/10.1371/journal.pone.0127849

7. Chyu MC, James CR, Sawyer SF, Brismée JM, Xu KT, Poklikuha G. et al. Effects of tai chi exercise on posturography, gait, physical function and quality of life in postmenopausal women with osteopaenia: a randomized clinical study. Clin Rehabil 2010 Dec;24(12):1080-90.

https://doi.org/10.1177/0269215510375902

8. Wayne PM, Kiel DP, Buring JE, Connors EM, Bonato P, Yeh GY. et al. Impact of Tai Chi exercise on multiple fracture-related risk factors in post-menopausal osteopenic women: a pilot pragmatic, randomized trial. BMC Complement Altern Med 2012; $12: 7$.

https://doi.org/10.1186/1472-6882-12-7

\section{POMENOPAUZINIO AMŽIAUS MOTERŲ, KURIOMS NUSTATYTA OSTEOPOROZE், GYVENIMO PILNATVE்S KAITA PO TRUMPALAIKÉS TAI CHI POVEIKIO PROGRAMOS TAIKYMO \\ E.Lašinytė, K.Berškienė, V.Mauricienė \\ Raktažodžiai: osteoporozė, SF-36 klausimynas, Tai Chi. Santrauka \\ Tikslas. İvertinti pomenopauzinio amžiaus moterų, kurioms}


nustatyta osteoporozè, gyvenimo pilnatvės kaitą po Tai Chi užsièmimų taikymo.

Medžiaga ir metodai. Tyrime dalyvavo 13 pomenopauzinio amžiaus moterų, sergančių osteoporoze, kurioms buvo taikyta aštuonių savaičių trukmès Tai Chi poveikio programa. Tai Chi programa buvo vykdoma du kartus per savaitę ir užsiėmimai trukdavo po vieną valandą. Gyvenimo pilnatvẻ buvo vertinta du kartus: prieš ir po aštuonių savaičių Tai Chi poveikio programos. Gyvenimo pilnatvès įvertinimui pasitelktas SF-36 klausimynas.

Rezultatai. Po Tai Chi užsièmimų programos taikymo pagerejo pomenopauzinio amžiaus moterų, kurioms nustatyta osteoporozė, gyvenimo pilnatve - statistiškai reikšmingai $(\mathrm{p}<0.05)$ geresni re- zultatai nustatyti trijose iš aštuonių sričių, kurios vertinamos SF36 klausimynu: skausmo, bendrojo sveikatos vertinimo ir veiklos apribojimo dèl emocinių sutrikimų.

Išvados. Gauti rezultatai parodè teigiamus pokyčius fizinės ir psichinès sveikatos srityse. Tačiau reikalingi tolesni tyrimai, siekiant išsiaiškinti, kaip Tai Chi programos taikymas paveiktų kitas gyvenimo sritis.

Adresas susirašinėti: ema.lasinyte@gmail.com

Gauta 2018-04-07 